\title{
Impact of Ottoman Scientific Advancement in the Era of Sultan Muhammad al-Fatih (Mehmed the Conqueror) towards the Ottoman Scientific Zenith
}

\author{
Ammalina Dalillah Mohd Isa \\ Universiti Kebangsaan Malaysia \\ Email: ammalina05mohdisa@gmail.com \\ Roziah Sidik @ Mat Sidek \\ Universiti Kebangsaan Malaysia \\ Email: roziah@ukm.edu.my
}

\author{
Doi:10.5901/mjss.2014.v5n29p81
}

\begin{abstract}
The main criteria of a developed country lie in its scientific and technological development. Nevertheless, in developing those fields in a nation, it starts with its ruler and his rule. In the case of the Ottomans, the field of science and technology was stagnant in the early stage of their rule. Through transformations in the field of science and technology undertaken by Sultan Muhammad al-Fatih (Mehmed the Conqueror) as the seventh ruler of the Ottomans during his reign, this field experienced its advancement era. In the subsequent years (post-Sultan Muhammad al-Fatih era), the field of science and technology attained its golden age. Hence, the objective of this paper is to analyse the impact of scientific advancement in the era of Sultan Muhammad al-Fatih towards the Ottoman scientific zenith in the subsequent era. This study employed a qualitative approach via a historical research design and was analysed using a method of content analysis and deduction by examining authoritative sources in Ottoman studies. Through this study, it was found that the transformation brought about by Sultan Muhammad alFatih in the field of science and technology during his era succeeded in elevating the scientific fields of the Ottomans to a new height of glory. The impact can be seen in material and non-material cultures of the Ottoman society in post-Sultan Muhammad al-Fatih era.
\end{abstract}

Keywords: Muhammad al-Fatih; Ottoman Science; Islamic science and technology; 15th century;

\section{Introduction}

The field of science and technology first emerged in the Ottoman Empire after Sultan Orhan I established the first madrasah institution in Iznik in 1331(Inalcik, 1973). Since then, this field was worked by only certain individuals who had the need for the field since religious field was more of a priority at that time. This shows that the field of science and technology was not much studied, let alone practiced, by the Ottomans on the whole. This caused the Ottoman scientific field to be stagnant or stunted. The disciplines worked on by the Ottomans were only those scientific fields obtained and inherited from previous kingdoms such as the Seljuk. However, the future of the Ottoman scientific field eventually changed when this field advanced after Sultan Muhammad al-Fatih ascended to the throne and it flourished with vitality after Constantinople was opened by him in 1453 as stated by Ayduz (2010). There were various fields of scientific knowledge which progressed to a greater height such as medicine, astronomy, mathematics and engineering. The advancement in those fields was a fruit of labour of the role and transformations carried out by Sultan Muhammad alFatih during his reign.

\section{Ottoman Science Before the Era of Sultan Muhammad al-Fatih}

The field of science and technology in the Ottoman Caliphate can be discussed in two stages. The first stage is the growth and activities which happened during the early era of Ottoman establishment and the second stage is the development and activities of science and technology which occurred during the golden age of the Ottoman Caliphate. The first stage covers the ruling era of Sultan Orhan I up to that of Sultan Murad II, which began in 1324 until 1451, while the second stage encompasses the reign of al-Fatih which began in 1451 until the year 1600. The field of science and technology in the Ottoman Caliphate after 1600 is not deliberated in this paper as in that year Islamic scientific traditions 
ended. In the following years, the field of science and technology of the Ottomans went through modernizing era following Western scientific traditions (Ihsanoglu, 2002).

The field of science and technology was first introduced and worked on in the Ottoman State through learning in madrasahs. In 1331, after Bursa had been occupied, madrasah institution was established by the Ottomans under Sultan Orhan I in Iznik. Nevertheless, the field of science and technology did not go through much development as stated by Ayduz (2006) in his work: "The Ottomans inherited Islamic science and did not open new horizons to advance it further. Instead they spent their efforts in developing the application of this heritage". This is supported by Ihsanoglu (2005). According to Ihsanoglu (2005), before Ottoman science reached the era of progress under the rule of Sultan Muhammad al-Fatih, the field of science and technology was not developed to a greater height.

Based on quotes from both scholars, Ottoman science and technology did not grow and this was linked to the low level of science inculcation into the Ottoman society in that age and this can be attributed to several factors. Among them was that the field of science and technology was not recognised as a formal education as written in the state education policy. Even though the field of science and technology emerged in Ottoman education institutions, it was however not taught in all madrasahs formally. This was because the subjects were taught based on requests from the students or on the wish of the teacher at the madrasah. If there was no request or there was no skilled teacher in that field, the subject was not delivered at the madrasah (Ihsanoglu, 2005). This caused the discipline to stagnate and not spread in the Ottoman society.

The second factor was due to the absence of necessity or specific use for the field in their life, resulting in no initiatives being taken by any individual or organisation to develop the field. Therefore, the Ottoman society only learnt and applied the field of science and technology inherited from previous kingdoms of Seljuk, Egypt, Persia and Turkestan without developing it to a higher level such as critically studying them or digging new treasure of knowledge base on the inherited knowledge (Ayduz, 2010). It was sufficient to use the inherited knowledge only.

The next factor was that more focus was given by the Ottoman society to the sciences of shari'ah such as tajweed, shari'ah, exegesis, and the likes. As proof, the growth of these fields can be seen in the existence of scholarly figures in those fields and in their published original works. Among shari'ah scholars who emerged were Davud $b$. Mahmud elKayseri (d. 751A.H./1350-1351A.D.), Taceddin el-Kurdi and Alaeddin Esved. In the era of Sultan Orhan I reign, Davud b. Mahmud el-Kayseri was the first individual to receive the title 'professor' in Iznik Madrasah for his work in religion, philosophy and mysticism, as well as his review of the work of Fahruddin al-Razi (d. 606H/1209-1210M) and commentary work on Fususu I-Hikem written by Muhyiddin Ibnu I-Arabi (d. 638H/1240-1241M) (Ihsanoglu, 2002). Consequently, the situation did not give space for the field of science and technology to flourish.

Another factor was that there was no encouragement from the leaders to develop science and technology in the Ottoman State. This is more or less given as most of the Ottoman sultans prior to al-Fatih focused more on the affairs of territorial expansion and military politics considering the unstable political situations of the era. This is because at the onset of Ottoman dynasty until the age of Sultan Muhammad al-Fatih, The Ottomans were constantly threatened by European powers on the borders of the Ottoman territory. Meanwhile, within the territory Ottoman was threatened by rebel groups. Hence, peace and stability of the state was more emphasised as compared to other issues.

Among the early fields of science and technology applied in the era were mathematics (more specifically geometry), medicine and astronomy. According to lleri (2011), those disciplines were central to the Islamic sciences in the Ottoman government. These fields were among the most important in the life of Ottoman society at that time. This was because the fields were needed to determine the time, know the geographical location of Ka'abah and calculate the accurate beginning time of prayers as well as the starting and end time of fasting in the month of Ramadan (Ayduz, 2010).

As for mathematics, its importance in the life of Ottoman society was, for instance, the application of geometry as a branch of mathematics in assisting philosophers estimating the origin of the universe. In addition, this field of knowledge also helped the jurists to edict fatwa and qadis in their court ruling (Ihsanoglu, 2002). Meanwhile, medicine was important for treatment of diseases and injuries suffered by particularly Ottoman soldiers. Therefore, it can be concluded that even though the field of science and technology was introduced since the era of Sultan Orhan I, the field did not progress due to several factors as discussed earlier on. Nevertheless, that era witnessed a rapid development in the field of shari'ah leading to the appointment of the first professor at the Iznik Madrasah.

\section{Ottoman Scientific Progress in the Era of Sultan Muhammad al-Fatih}

When Sultan Muhammad al-Fatih ascended the throne of the Ottoman State in 1451 after the demise of his father, Sultan Murad II, the fate of Ottoman science and technology changed for the better and turned into advancement. This was 
caused by the fact that the field of science and technology then received major attention in the government of Sultan Muhammad al-Fatih and that was partly due to his interest in the field. One after another, progress and advancement in the field of Ottoman science and technology took place. The progress and development can be seen and explained through the status of that field in the Ottoman Caliphate throughout the era of Sultan Muhammad al-Fatih which lasted until 1481 (Ihsanoglu, 2005; Ayduz, 2010).

The first change can be seen to occur when this field of knowledge started to gain the attention of the Ottoman society as compared to before. In the previous era, science attracted less attention of the people because there was no necessity for them to further the knowledge of science and technology. It was sufficient for certain quarter of the society to deepen the knowledge such as jurists and judges. Therefore, the Ottomans emphasised religious education only as stated by Ihsanoglu (2002). However, starting from the era of Sultan Muhammad al-Fatih, the field gained the attention as it was formally taught in Ottoman education institutions. This was because, according to Ihsanoglu (2004), the madrasah education institutions got the influence of curriculum prepared by Ali Kushju whose background was originally in rational science in the field of astronomy and mathematics. The yielded curriculum combined religious studies with rational science studies. Consequently, the field of science and technology became more recognised among the Ottoman public.

The acceptance and attention the Ottomans gave towards the field of science and technology was the first step towards advancement in that field. Next, the advancement and progress of Ottoman science can be seen through its applications in a vast manner in institutions not only in education but also in other institutions and industries such as hospitals. Hospitals which were also known as sifahane, darussihha, bimarhane, timarhane or dar al-Shifa were waqf institutions responsible for the affairs of public health regardless of status. They had the role of giving medical education and providing training services to trainee doctors in the aspect of their practical training (Ayduz, 2004).

After the conquest of Istanbul by Sultan Muhammad al-Fatih, many hospitals were built in Istanbul. The first hospital built there was Dar al-Shifa of Sultan Muhammad al-Fatih Mosque Complex in 1470. Before al-Faith era, hospitals had only one section which was for mental patients. When al-Fatih hospital was built, the section was enlarged to contain 70 rooms and 80 domes. It was even segregated into two sections for men and women (Ayduz, 2004). Besides, in treating mental patients, music was used as a method of treatment. Through this method of treatment, a branch of knowledge studies was discovered which was music study.

An institution that developed Ottoman science was the time keeping houses (muvakkithaner). This institution was a body which was responsible of taking care of keeping the time specifically prayer times. According Ayduz (2010) this institution was introduced in the Ottoman administration during the era of Sultan Murad II. However, in the era of Sultan Muhammad al-Fatih, this institution grew especially after the conquest of Istanbul. The progress of this institution was a result of original research, localisation of scientific knowledge and preparation of calendar which were massively put into effect in the era of Sultan Muhammad al-Fatih. Members of this institution were given some education in astronomy. Some of them also prepared the annual calendar and determined the early date of Ramadhan. According to Ihsanoglu (2002), the emergence of this institution was initiated by absence of observatory in the Ottoman State at that time. Hence, an institution was established to monitor and standardize prayer times.

In the era of Sultan Muhammad al-Fatih, the time keeping houses were built next to the mosque. Apart from keeping the time, this institution also trained students in the field of astronomy and even astrology. This was because the houses were equipped with simple astronomical equipment. However, not all time keeping hoses provided astronomical training to the students as this depended on the level of knowledge the chief of the house possessed. If the chief of the institution was not conversant in astronomy, the institution would not be made a centre of training for astronomy students (Ayduz, 2004).

Apart from that, changes which occurred from the aspects of activities and application in the field were more evident in the science of manufacturing engineering of warfare machinery particularly firearms technology. According to Danisman (2007), firearms were first introduced in the Ottoman army since early $14^{\text {th }}$ century. Since that moment, each Ottoman ruler gave a specific emphasis on the invention of more sophisticated weapon for battle use. Beginning from the era of Murad I, employment of cannons had long been used in wars. According to Ottoman historical sources, bronze cannons and steel cannons were invented to equip the war armament in military expeditions in Karaman in 1354 and 1358. However, great achievement in the industry of firearms manufacturing happened in the era of Sultan Muhammad al-Fatih through the invention of giant cannons which succeeded to bring down the fort wall of Constantinople in 1453.

The advancement achieved in producing giant cannons was a huge success in the field of science of weaponry manufacturing engineering at that time. Through the invention of the giant cannon or known as Shahee Cannon, it indirectly developed metallurgy field or alloy science in finding a strong alloy mixture and more sophisticated fabrication method of cannon body. Meanwhile, progress made in the field of metallurgy brought about the growth in a new industry namely mining. Before the reigning era of Sultan Muhammad al-Fatih, mining activities occurred so as to stabilize the 
nation's economy only and mining site was only in Kure. However, with the ascension of Sultan Muhammad al-Fatih as Ottoman ruler, the need for this raw material increased and this brought about growth and improvement of new mines such as in Serbia, Macedonia and Thrace (Murphey, 2012).

In addition to that, progress in ship dockyards also contributed towards Ottoman science in the era of Sultan Muhammad al-Fatih. This was due to the field of shipbuilding engineering which also achieved progress as encouraging as the production of giant cannons. The advancement was more significantly seen after Constantinople became the capital of the Ottoman State. Before Constantinople was successfully conquered by Sultan Muhammad al-Fatih, the Ottomans obtained a shipyard which functioned and was responsible for preparing ships readying for war. The shipyard was located in Gallipoli as stated by Hess (1970).

According to Agoston (2012), at that time, the Ottomans were only capable of building small ship with a single mast and lateen sail. After Constantinople was opened and made the administrative centre of the Ottoman State, a few shipyards were constructed in Ottoman territory. One of the important shipyards was the Galata Shipyard before its name was changed to Tersâne-i Âmire (imperial shipyard) on the Golden Horn (Toraman, Guvemli \& Bayramoglu, 2010). The specific date of construction of the shipyard is not known. However, according to Bostan (2000) the shipyard was built at the end of the 15th century. The complex contained a few sections which housed a mosque, several docks and a public hall. With the increase of naval shipyards, the technology of shipbuilding further advanced to being capable of building huge ships which could accommodate cannons for naval warfare.

Through the germination of industries and institutions, as well as due to contemporary needs of the Ottoman society, advancement of Ottoman scientific fields took place. Among them were astronomy and mathematics. Before the era of Sultan Muhammad al-Fatih, both disciplines only functioned in determining the time of prayer as well as calculating apportionment of inheritance. However, due to the high demand for the field in the era of Sultan Muhammad al-Fatih, new writings on this field were produced to fulfil those demands. They included Risalah al-Muhammadiyya fi al-Hisab and Ulug Bey Astronomical Table by Ali Kuschu. Similarly in the field of medicine, it went through development and new method discoveries in surgery. Among the works was Jarrāhiyāt al-Khāniyya which was authored by Sabuncuoglu who illustrated surgical methods (Ayduz, 2010).

\section{Role of Sultan Muhammad al-Fatih in Ottoman Scientific Advancement}

During his era, there were several matters which were given attention by Sultan Muhammad al-Fatih in ensuring the advancement and development of the field of science and technology. Among them were from the aspects of politics, economy and the construction of facilities and infrastructures. Al-Fatih also enacted policies and held dialogues with outside civilisations as well as other Islamic civilisations in developing scientific and technological fields during his era. Moreover, he himself went into those fields and encouraged his subjects to do the same. Table 1 shows in brief the role and transformations brought about by Sultan Muhammad al-Fatih in developing the field of science and technology in his ruling era.

Table 1. Role of Sultan Muhammad al-Fatih in Developing the Field of Science and Technology.

\begin{tabular}{|c|c|c|}
\hline No. & $\begin{array}{l}\text { Role of Sultan } \\
\text { Muhammad al-Fatih }\end{array}$ & Description \\
\hline 1 & Politics and Economy & $\begin{array}{l}\text { He took the step to stabilise and strengthen Ottoman political and economic states. Ayduz (2010) stated: } \\
\text { "Owing to the political stability and economic wealth of the reign of Mehmed, distinguished scholars and } \\
\text { artists of the Islamic world assembled in Istanbul". }\end{array}$ \\
\hline 2 & $\begin{array}{l}\text { Constructing facilities } \\
\text { and infrastructures }\end{array}$ & $\begin{array}{l}\text { Among them were Al-Fatih Madrasah Complex which was equipped with madrasah, mosque, public kitchen, } \\
\text { student accommodation, public baths, hospital and wards within one area, libraries throughout Ottoman } \\
\text { territories which housed various books of science and technology which were easily accessible by Ottomans, } \\
\text { new shipyard at the Golden Horn and canon manufacturing factory which was opened in Tophane as well as } \\
\text { mines in certain places in the Empire (Anameric \& Rukanci, 2006; Ihsanoglu, 2004; Ammalina \& Roziah, } \\
\text { 2014; Agoston, 2005; Murphey, 2012). }\end{array}$ \\
\hline 3 & $\begin{array}{l}\text { Improving old policies } \\
\text { and enacting new } \\
\text { policies }\end{array}$ & $\begin{array}{l}\text { An old education policy was improved by setting a new aim of Ottoman education which was "to pursue the } \\
\text { fundamental sciences prescribed by the religious law and their ancillaries, as well as all the other noble } \\
\text { transmitted sciences" which formalised rational science education in Ottoman madrasahs (Ihsanoglu, 2005). } \\
\text { Territorial expansion policy opened the opportunity for the field of engineering in manufacturing of weaponry } \\
\text { to flourish (Jamsari et al., 2012). New policy which was sanctioned was maritime policy which had the } \\
\text { objective of conquering territories of non-Muslim rulers who fought Islam specifically the Byzantine Empire } \\
\text { through continuously seizing their towns and territories around waters (Hess, 1970). Resettlement policy to } \\
\text { attract the people of different background, religion, race and occupation rejuvenated Istanbul (Oz, 1999). }\end{array}$ \\
\hline
\end{tabular}




\section{Holding dialogues with}

4 foreign civilisations and other Islamic civilisations

Getting involved in the field of science and

5 technology and encouraging his subjects to do the same.
Sultan Muhammad al-Fatih held dialogues with Western civilisations such as Europe (Hungary, Byzantine and Italy), Asian civilisation (Trabizond) and other Islamic civilisation (Turkmen), be it with individuals or through government cooperation to develop the field of science and technology (Ammalina \& Roziah, 2013).

Al-Fatih also carried out studies in shipbuilding technology and geography to get new information in both fields [Hess, 1970; Ayduz, 2010). He would give rewards to students and teachers who excelled in Ottoman madrasahs (al-Salabi, 2011). He also called on governors of Ottoman territories to participate in the process of advancing science and technology by giving them encouragement to build and set up madrasah institutions and multiply the number of public libraries so that the field of science and technology would spread throughout the Ottoman Empire and not intensified in Istanbul only (al-Salabi, 2011; Ihsanoglu, 2004)

\section{Impact of Ottoman Scientific Advancement of Sultan Muhammad al-Fatih era}

The result of advancement brought by Sultan Muhammad al-Fatih gave numerous positive impacts which further advanced Ottoman scientific field until it reached its zenith under the rule of Sultan Sulaiman al-Qanuni (Suleiman the Magnificent) in the 16th century. The impact of Al-Fatih-era scientific advancement can be seen through material and non-material cultures of the Ottomans in the era of post-Sultan Muhammad al-Fatih rule. Table 2 explains the impact of Ottoman scientific advancement in the era of Sultan Muhammad al-Fatih on Ottoman scientific glory.

\section{Table 2. Impact of Ottoman Scientific Advancement in Sultan Muhammad al-Fatih Era}

\section{No. Impact on Non-Material Culture Impact on Material Culture}

1 Sustainability of the policies of Sultan Muhammad al-Fatih which was Publication of works in various fields of science and technology which carried out by Ottoman rulers of post-Sultan Muhammad al-Fatih era consisted of translation works, commentaries and original publications which includes education policy, maritime policy, settlement policy (Ihsanoglu, 2002). and territorial expansion policy (Ihsanoglu, 2005; Jamsari, Isa, \& Ashari, 2012; Hess, 2007; Oz, 1999).

2 Advancement of previous Ottoman scientific fields namely medicine, astronomy, mathematics, geography and manufacturing technology and emergence and development of new sciences such as music, cartography and navigation (Sari, 2014; Unat, 2014; Casale, 2010; Abbatouy, 2014; Ammalina \& Roziah, 2014).

3 Enculturation of Islamic science in Ottoman society which can be seen though the rise in the number of scholars in the era of postSultan Muhammad al-Fatih rules (Zadah, 1975).
Advancement of old institutions and industries such as madrasahs, hospitals and shipbuilding as well as weaponry and the emergence of new institutions such as observatory and medical schools (Tekelfi, 2014; Ayduz, 2010; Ihsanoglu, 2002; Bostan, 2000; Agoston, 2005)

Creation of new technological innovations in the field of astronomy (mural quadrant, sextant and astronomical clock), geography (world map) and shipbuilding technology (agriba, barca and kalyon) (Ayduz, 2010; Tekelfi, 2014; Soucek, 2008; Turkish Cultural Foundation, 2014)

\section{Conclusion}

The development brought by Sultan Muhammad al-Fatih into the Ottoman scientific field during his reign gave a huge impact to the scientific development of the ensuing Ottoman era. Through sustained policies carried out during postSultan Muhammad al-Fatih era, the scientific field of the Ottomans further advanced and eventually gave birth to a scientific culture within the Ottoman society. As a result, new institutions and industries emerged in Ottoman scientific fields which facilitated the undertaking of various new studies. This resulted in the publication of many new works, be it original publication or translation work or a mixture of both, in Ottoman scientific fields as well as the birth of innovations in the field of science and manufacturing technology.

\section{Acknowledgement}

This study is financed by the Research Group of Arabic Culture and Islamic Civilization (KUKAPI, DPP-2014-068), UKM; the Action/Strategic Research Project (PTS-2012-061; PTS-2012-124; PTS-2014-067; PTS-2014-068), UKM; the University-Industry Incentive Grant (SAKTI: INDUSTRI-2012-006), UKM; the Research Group of Modelling Interaction Between Civilisations (FRGS/1/2012/SSI05/UKM/02/1); and the Arus Perdana Project (AP-2012-001; AP-2013-017; AP2014-006), UKM.

\section{References}

Abattouy, M., Al-Hassani, S., El-Gomati, M., Ayduz, S., Konur, S., Nizamoglu, C., Brennan, A., Coles, M., Fenn, I., Nazir, A. \& Morris, M. 
(2014). Piri Reis: A Genius 16th-Century Ottoman Cartographer and Navigator. Muslim Heritage. [Online] Available: http://muslimheritage.com/article/piri-reis-genius-16th-century-ottoman-cartographer-and-navigator [14 Ogos 2014].

Agoston, G. (2005). Guns for the Sultan. UK: Cambridge University Press.

Agoston, G. (2012). Ottoman Military Organization (Up to 1800). The Encyclopedia of War. Vol. 1. Martel, G (ed.). Blackwell Publishing Ltd.

Anameric, H. \& Rukanci, F. (2006). Libraries as Scientific, Educational and Cultural Institutions in the Ottoman Empire (XIVth - XVIIth Centuries). Libri, 5, 252-263.

Ayduz, S. (2006). The Role of Translation in the Eighteen Century: Transfer of Modern Science and Technology to the Ottoman State. Foundation of Science, Technology and Civilisation. [Online] Available: http://www.muslimheritage.com/uploads/Transfer_of_ Modern_Science_Technology_Ottoman_State.pdf [5 Nov 2012].

Ayduz, S. (2010). Ottoman Contributions to Science and Technology: Some Examples from Medicine, Astronomy and Geography. Journal of Islamic Research, 21(2), 127-142.

Bostan, I. (2000). Ottoman Maritime Arsenals and Shipbuilding Technology in the 16th and 17th Century. In. The Great Ottoman, Turkish Civilisation. Vol. 3. Cicek, K (ed.). Ankara: Yeni Turkiye.

Casale, G. (2010). The Ottoman Age of Exploration. New York: Oxford University Press, Inc.

Danisman, G. (2007). Ottoman Mining and Metal Working in the Balkans: Its impact on Fire-Arms Technology of Southeast Europe. Foundation of Science,Technology and Civilisation. [Online] Available: http://www.muslimheritage.com/uploads/Ottoman Mining_Metal_Working.pdf [5 Nov 2012].

Hess, A. C. (1970). The Evolution of the Ottoman Seaborne Empire in the Age of the Oceanic Discoveries, 1453-1525. The American Historical Review, 75(7), 1892-1919.

Ihsanoglu, E. (ed.). (2002). History of The Ottoman State, Society \& Civilisation. Vol. 2. Istanbul: IRCICA.

Ihsanoglu, E. (ed.) (2004). Science, Technology and Learning in the Ottoman Empire. Britain: Ashgate Publishing Limited.

Insanoglu, E. (2005). Institutionalisation of Science in the Medreses in Pre-Ottoman and Ottoman Turkey. In. Irzik, G. \& Guzeldere, G. (eds). Turkish Studies in the History and Philosphy of Science, pp. 265-283. Netherlands: Springer.

Ileri, I. (2011). Ali al-Qushji and His Contributions to Mathematics and Astronomy. Muslim Heritage. [Online] Available: http://muslimheritage.com/article/ali-al-qushji-and-his-contributions-mathematics-and-astronomy [9 Ogos 2014].

Inalcik, H. (1973). The Ottoman Empire: The Classical Age 1300-1600. New York: Praeger Publishers Inc.

Isa, A.D.M. \& Roziah, S. (2013). Dialog antara Sultan Muhammad al- Fatih dengan Tamadun Eropah (Dialogue between Sultan Muhammad al-Fatih with the European Civilization). In. Prosiding Seminar Isu Ketamadunan dan Cabaran Semasa, pp. 51-65.

Isa, A.D.M., \& Sidik, R. (2014). Shipbuilding Industry in the Era of Sultan Muhammad al-Fatih. In. Proceeding of International Symposium on Islam, Civilisation and Science, pp. 420-437. UKM \& KU: Institute of Islam Hadhari (IIH) and Centre of Islamic Area Studies (KIAS).

Jamsari, E.A., A.D.M., Isa \& M.Z.A.H., Ashari. (2012). Sultan Muhammad al-Fatih: Ottoman's Great Strategic Planner. Middle-East Journal of Scientific Research, 20(12), 2158-2163. http://www.idosi.org/mejsr/mejsr20(12)14/89.pdf

Murphey, R. (2012). The Ottoman Economy in the Early Imperial Age. In The Ottoman World. London \& New York: Routledge.

Ottoman Sailing Ships from Galleys to Galleons. In Turkish Cultural Foundation. [Online] Available: http://www.turkishculture.org/ military/naval/ship-building-171.htm?type=1 [15 March 2014]

Oz, M. (1999). Some Notes on the Changesin the Early Ottoman Societyfrom the $14^{\text {th }}$ to the late $15^{\text {th }}$ Century. Edebiyat Fakültesi Dergisi (Journal of Faculty of Letters), Special Issue, 33-42.

al-Salabi, 'Ali Muhammad Muhammad. (2011). Faktor Kebangkitan dan Sebab Kejatuhan Kerajaan 'Uthmaniyyah (Factors behind the Rise and Fall of the Ottoman Empire). Trans. by Salehan Ayub. Kuala Lumpur: Pustaka Salam.

Sari, N. (2014). Ethical Aspects of Ottoman Surgical Practice. Muslim Heritage. [Online] Available: http://muslimheritage. com/article/ethical-aspects-ottoman-surgical-practice [14 Ogos 2014]

Soucek, S. (2008). Studies in Ottoman Naval History and Maritime Geography. Istanbul: The ISIS Press.

Tekelfi, S. (2005). The Observational Instruments of Istanbul Observatory. Foundation of Science, Technology and Civilisation. [Online] Available: http://www.muslimheritage.com/uploads /IstanbulObservatory.pdf [9 Ogos 2014]

Toraman, Guvemli \& Bayramoglu. (2010). Imperial Shipyard (Tersane-I Amire) in the Ottoman Empire in 17th Century: Management and Accounting. Spanish Journal of Accounting History, 13 (Dec), 191-226.

Unat, Y. (2012). Development of Astronomy in Ottomans. [Online] Available: https://www.academia.edu/5818584/Development_of_ Astronomy in Ottomans [19 Ogos 2014]

Zadah, T. (1975). al-Shaqaiq al-Nu'maniyyah. Beirut: Dar al-Kitab al-'Arabi. 